\title{
Adenosine-Mediated Presynaptic Modulation of Glutamatergic Transmission in the Laterodorsal Tegmentum
}

\author{
Elda Arrigoni, ${ }^{1}$ Donald G. Rainnie, ${ }^{1,2}$ Robert W. McCarley, ${ }^{1}$ and Robert W. Greene ${ }^{1}$ \\ ${ }^{1}$ Harvard Medical School and Veterans Administration Medical Center, Department of Psychiatry, Brockton, \\ Massachusetts 02401, and 2Emory University, Department of Psychiatry, Atlanta, Georgia 30322
}

The laterodorsal tegmentum (LDT) neurons supply most of the cholinergic tone to the brainstem and diencephalon necessary for physiological arousal. It is known that application of adenosine in the LDT nucleus increases sleep in vivo (Portas et al., 1997) and directly inhibits LDT neurons in vitro by activating postsynaptic adenosine $A_{1}$ receptors (Rainnie et al., 1994). However, adenosine effects on synaptic inputs to LDT neurons has not been previously reported. We found that both evoked glutamatergic EPSCs and GABAergic IPSCs were reduced by adenosine $(50 \mu \mathrm{M})$. A presynaptic site of action for adenosine $A_{1}$ receptors on glutamatergic afferents was suggested by the following: (1) adenosine did not affect exogenous glutamatemediated current, (2) adenosine reduced glutamatergic miniature EPSC (mEPSC) frequency, without affecting the amplitude, and (3) inhibition of the evoked EPSC was mimicked by the $A_{1}$ agonist N6-cyclohexyladenosine (100 nM) but not by the $A_{2}$ agonist N6[2-(3,5-dimethoxyphenyl)-2-(methylphenyl)-ethyl]-adenosine (10 $\mathrm{nm})$.

Cholinergic neurons of the mesopontine laterodorsal tegmental nucleus (LDT) and pedunculopontine tegmental nucleus (PPT), together with the cholinergic neurons of the basal forebrain (BF), constitute to the cholinergic "arousal system." Most of these cholinergic neurons selectively increase their discharge rate during the two states of electroencephalographic (EEG) activation: waking and rapid eye movement (REM) sleep (Szymusiak and McGinty, 1989; Semba, 1991; Jones, 1993; Szymusiak, 1995). Cortical EEG activation and behavioral arousal depends, at least in part, on excitatory cholinergic projections to the thalamus. An increased cholinergic tone can depolarize thalamocortical neurons, inducing a voltage-dependent shift in their discharge pattern from a burst firing mode to a more responsive single-spike mode, which is associated with cortical activation (Steriade et al., 1993). During the transition from waking to sleep, the firing rate of LDT/PPT neurons markedly decreases, reducing the cholinergic tone of their target sites and thus facilitating the transition to sleep (Steriade et al., 1990). Several "sleep factors" have been proposed to regulate the transition from waking to sleep. One

Received July 21, 2000; revised Nov. 6, 2000; accepted Nov. 24, 2000.

This work was supported by a Merit Award from The Department of Veterans Affairs to R.W.G., and by Specialized Center of Research (SCOR) Grant NHLBIHL60292. E.A. was supported by the University of Milan, Italy and by SCOR Grant NHLBI-HL60292. We also thank Dr. M. R. Palmer for help in the preparation of this manuscript.

Correspondence should be addressed to Dr. Robert W. Greene, Harvard Medical School and Veterans Administration Medical Center, Laboratory of Neuroscience, 151-C, 940 Belmont Street, Brockton, MA 02401. E-mail: robert_greene@HMS.harvard.edu.

Copyright (C) 2001 Society for Neuroscience $0270-6474 / 01 / 211076-10 \$ 15.00 / 0$
The $\mathrm{A}_{1}$ receptor antagonist 8-cyclopentyltheophylline (CPT; $200 \mathrm{~nm})$ potentiated the evoked EPSCs, suggesting the presence of a tonic activation of presynaptic $A_{1}$ receptors by endogenous adenosine. The adenosine kinase inhibitor, 5-iodotubercidin $(10 \mu \mathrm{M})$, mimicked adenosine presynaptic and postsynaptic effects. These effects were antagonized by CPT or adenosine deaminase $(0.8 \mathrm{lU} / \mathrm{ml})$, suggesting mediation by increased extracellular endogenous adenosine. Together, these data suggest that the activity of LDT neurons is under inhibitory tone by endogenous adenosine through the activation of both presynaptic $A_{1}$ receptors on excitatory terminals and postsynaptic $A_{1}$ receptors. Furthermore, an alteration of adenosine kinase activity modifies the degree of this inhibitory tone.

Key words: adenosine; evoked EPSC; synaptic modulation; laterodorsal tegmental (LDT) nucleus; sleep; electrophysiology; A1 receptors; adenosine kinase inhibitor

such factor, adenosine, has been shown to promote sleep and increase EEG slow wave activity in a manner similar to that observed at the onset of sleep (for review, see Radulovacki, 1985; Strecker et al., 2000). Moreover, adenosine antagonists, such as caffeine and theophylline, are known to suppress sleep (for review, see Fredholm et al., 1999). We recently proposed that adenosine may mediate these state-dependent changes by a direct $A_{1}$ receptor-mediated inhibition of neurons of the cholinergic arousal system (Rainnie et al., 1994). This hypothesis is supported by subsequent observations that (1) local administration of adenosine into either the LDT/PPT or the cholinergic area of the BF in cats (Portas et al., 1997) and in BF in rats (Basheer et al., 1999) decreases waking, (2) local administration of the adenosine transport inhibitor S(4-nitrobenzyl)-6-thioinosine (NBTI) into the BF promotes sleep in cats (Porkka-Heiskanen et al., 1997), whereas application in the $\mathrm{BF}$ of adenosine $\mathrm{A}_{1}$ receptor antagonist increases waking (Strecker et al., 2000), (3) sleep deprivation induces a region-specific increase in $\mathrm{BF}$ adenosine levels that decline after subsequent recovery sleep (Porkka-Heiskanen et al., 1997; Basheer et al., 1999; for review, see Strecker et al., 2000), and (4) $A_{1}$ receptor activation inhibits the firing activity of wake active neurons in the BF of rats and cats (Alam et al., 1999; Thakkar et al., 1999).

Adenosine inhibits $60-70 \%$ of LDT/PPT neurons recorded in whole-cell patch-clamp configuration by activation of postsynaptic $\mathrm{A}_{1}$ receptors coupled to an inwardly rectifying $\mathrm{K}^{+}$conductance (Rainnie et al., 1994). However, the activity of $100 \%$ of LDT/PPT and BF neurons recorded with extracellular recording 
electrodes in vitro was inhibited by similar concentrations of adenosine, suggesting an additional presynaptic locus of adenosine action. In the present study, we have investigated the role of exogenous and endogenous adenosine in regulating synaptic transmission in the LDT nucleus.

\section{MATERIALS AND METHODS}

Slice preparation. Experiments were performed in vitro on coronal brainstem slices that were prepared using standard methods (Luebke et al., 1993). Briefly, female Long-Evans hooded rats (21-30 d old) were decapitated after isofluorane-induced anesthesia, and their brain were rapidly removed. Coronal slices $(400 \mu \mathrm{m})$ were cut with an EMS 3000 Vibratome (Electron Microscopy Science, Fort Washington, PA) at $4^{\circ} \mathrm{C}$ in artificial CSF (ACSF). Two or three slices containing the LDT nucleus were transferred to a holding chamber and incubated at room temperature in continuously oxygenated ACSF for $\sim 1 \mathrm{hr}$ before use.

Recording. Individual slices were transferred to the recording chamber where they were submerged and perfused with pregassed ACSF (1.8 $\mathrm{ml} / \mathrm{min}$ ) at $32^{\circ} \mathrm{C}$. Recordings were made with the "blind" whole-cell technique (Blanton et al., 1989) in voltage-clamp mode using an Axopatch-1D amplifier (Axon Instruments, Foster City, CA). Data acquisition and analysis were conducted with a Digidata 1200B interface and Clampex 8.0 software (Axon Instruments). Patch electrodes were pulled from borosilicate glass tubing (outer diameter $1.5 \mathrm{~mm}$; inner diameter $0.86 \mathrm{~mm}$, with filament) on a P97 pipette puller (Sutter Instrument, Novato, CA) and had resistances of 7-10 $\mathrm{M} \Omega$ when filled with the recording medium. Series resistance was monitored at regular intervals throughout the course of the experiments with voltage pulses $(-10 \mathrm{mV}$; $100 \mathrm{~Hz}$ ).

Evoked (ev) EPSCs and evIPSCs were electrically induced after stimulation of afferents to the LDT with a bipolar electrode PK/3 (FHC, Bowdoinham, ME) placed on the surface of the slice close to the dorsolateral border of the ipsilateral LDT, rostral-caudal extent (between -8.72 and $-9.30 \mathrm{~mm}$ relative to Bregma). The regions of the stimulation correspond to the cuneiform nucleus (rostral sections) and parabrachial nucleus (caudal sections). An isolated constant-current source, Master-8 (A.M.P.I. Jerusalem, Israel), was used to generate squarewave pulses of direct current (300-3000 $\mu \mathrm{A} ; 200 \mu$ sec duration; $0.3 \mathrm{~Hz}$ ). The stimulation trigger was controlled by Clampex 8.0 software. Unless specified, all evEPSCs were captured at $V_{\mathrm{h}}-60 \mathrm{mV}$ and are displayed as averages of 10 current traces.

Spontaneous, miniature EPSCs (mEPSCs) were recorded in the presence of tetrodotoxin (TTX; $1 \mu \mathrm{M}$ ). Continuous recordings of $60 \mathrm{sec}$ epochs were obtained with Clampex 8.0 software, low-pass-filtered at 1 or $2 \mathrm{kHz}$, and digitized at $5 \mathrm{kHz}$. Events were semiautomatically analyzed off-line with Mini Analysis 4.0 software (Synaptosoft, Leonia, NJ). Traces were then visually examined, and erroneous events were rejected. Events were ranked by amplitude and inter-event interval for preparation of cumulative probability distribution.

Data were compared statistically with either the nonparametric Kolmogorov-Smirnov test (K-S test) or Student's $t$ test. Significance was assessed at $p<0.05$. All data are expressed as mean $\pm \mathrm{SE}$. To establish whether the evEPSC and evIPSC amplitudes were affected by drug application, the average amplitude of 10 evEPSCs/evIPSCs recorded under control conditions and 10 evEPSCs/evIPSCs recorded during the drug application were compared by using the Student's $t$ test (unpaired). Significance was assessed $(p<0.05)$ to select "responding" neurons. The amplitudes of the evEPSC/evIPSC for the remaining neurons (termed "nonresponding") were not significantly different from control $(p>0.1)$, and so they were excluded from the averaging of the response amplitude.

Solutions and drugs. The control ACSF solution for slice preparation and recording contained (in $\mathrm{mM}$ ): $\mathrm{NaCl} 124, \mathrm{KCl} 2, \mathrm{KH}_{2} \mathrm{PO}_{4} 3, \mathrm{MgCl}_{2}$ 1.3, $\mathrm{CaCl}_{2} 2.5, \mathrm{NaCO}_{3} 26$, glucose 10, $\mathrm{pH} 7.35$, and 315-320 mOsm when gassed with $\mathrm{O}_{2} 95 \%$ and $\mathrm{CO}_{2} 5 \%$. The patch recording medium contain (in mM): K-gluconate $120, \mathrm{KCl} \mathrm{10,} \mathrm{MgCl}_{2}$ 3, HEPES 10, MgATP 2, NaGTP 0.2, pH 7.2, adjusted with KOH; 280 mOsm. The drugs used in these experiments were adenosine, adenosine deaminase (type VI), $\mathrm{D}(-)$-2-amino-5-phosphonopentanoic acid (APV), (-)-bicuculline methiodide (BMI), N6-cyclohexyladenosine (CHA), CPT; 6,7dinitro-quinoxaline-2,3-dione (DNQX), N6-[2-(3,5-dimethoxyphenyl)2-(methylphenyl)-ethyl]adenosine (DPMA), dipyridamole, glutamate, 5-iodotubercidin (ITU), NBTI, and TTX. Drugs were all obtained from Sigma/RBI (Natick, MA). The stocks of CPT, dipyridamole, DPMA, DNQX, ITU, and NBTI were dissolved in dimethyl sulfoxide (DMSO)
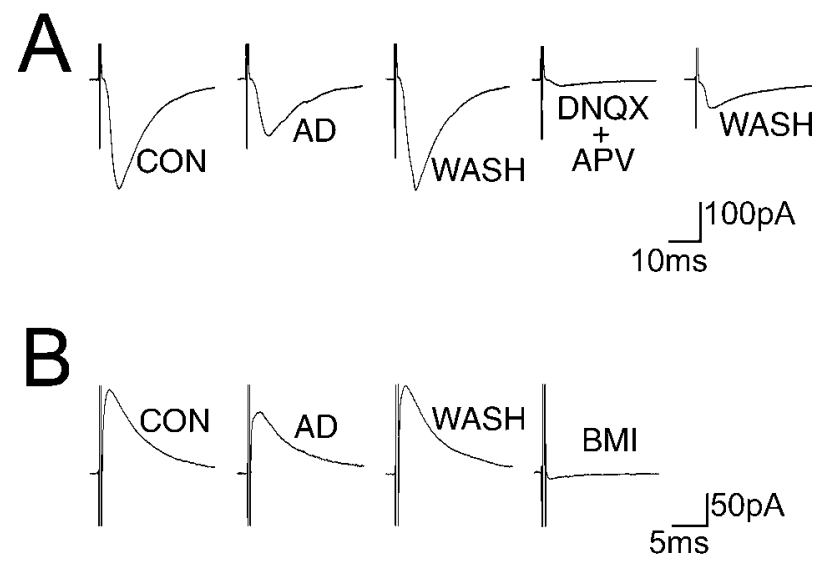

Figure 1. Adenosine modulates both glutamatergic- and GABAergicevoked synaptic transmissions. $A$, Glutamatergic evEPSCs are inhibited by adenosine $(A D)$. The evEPSC recorded at $V_{\mathrm{h}}=-60 \mathrm{mV}$ is reversibly reduced by adenosine $(50 \mu \mathrm{M})$ and blocked by perfusion of glutamatergic receptor antagonists DNQX $(20 \mu \mathrm{M})$ and APV $(100 \mu \mathrm{M})$. $B$, In another neuron, a GABAergic evIPSC is inhibited by adenosine. The evIPSC recorded in the presence of DNQX and APV $\left(V_{\mathrm{h}}=-40 \mathrm{mV}\right)$ is reversibly reduced by adenosine and blocked by $\mathrm{GABA}_{\mathrm{A}}$ receptor antagonist BMI $(20 \mu \mathrm{M})$. Each current trace is the average of 10 evEPSCs or evIPSCs.

before being added to ACSF (final concentration of DMSO $<0.1 \%$ ). The ITU stock was protected from the light and added to the ACSF in a perfusion tube protected from ambient light exposure. In some experiments, glutamate $(1 \mathrm{mM})$ was transiently applied $(0.8-1.5 \mathrm{sec})$ by pressure ejection from a micropipette (1-2 $\mu \mathrm{m}$ tip diameter) positioned near the recorded cell using a picospritzer (General Valve, Fairfield, NJ). Allura red food dye (Durkee, San Francisco, CA) was added to the micropipette ( $2 \mu \mathrm{l}$ in $2 \mathrm{ml}$ ACSF) to monitor the area of the slice involved in the pressure injection protocol. This dye by itself had no electrophysiological effects on LDT neurons $(n=2)$.

\section{RESULTS}

\section{Adenosine inhibits both excitatory and inhibitory evoked synaptic transmission in LDT neurons}

Adenosine has a direct effect on LDT excitability by activation of postsynaptic adenosine $\mathrm{A}_{1}$ receptors (Rainnie et al., 1994); however, the effect of adenosine on the synaptic input to these neurons was not known. In the present work we addressed this issue. Electrical stimulation of the ipsilateral border of the LDT (see Materials and Methods) induced a reproducible evEPSC in most of the LDT neurons recorded $\left(86 \% ; n=92 ; V_{\mathrm{h}}=-60 \mathrm{mV}\right)$. Application of non-NMDA and NMDA receptor subtype specific antagonists DNQX $(20 \mu \mathrm{M})$ and APV $(100 \mu \mathrm{M})$ completely blocked the evEPSCs in all neurons recorded $(n=27)$, indicating that they were mediated by glutamate release (Fig. $1 A$ ), similar to that observed in guinea pig (Sanchez and Leonard, 1996). These results are consistent with anatomical data that LDT neurons receive glutamatergic projections (for review, see Semba, 1999) and have both glutamatergic AMPA and NMDA receptors (Inglis and Semba, 1996). Additionally, in 11 of these 27 neurons, glutamatergic antagonists blocked the evEPSC and unmasked a residual evIPSC. The evIPSCs were recorded at different holding potentials between -80 and $-40 \mathrm{mV}$, revealing an average reversal potential of $-62.7 \pm 3.3 \mathrm{mV}(n=6)$, and were sensitive to the $\mathrm{GABA}_{\mathrm{A}}$ receptor antagonist BMI $(20 \mu \mathrm{M} ; n=4)$, suggesting mediation by $\mathrm{GABA}_{\mathrm{A}}$ receptor activation (Fig. $1 B$ ). In many areas of the CNS, adenosine inhibits both glutamatergic and GABAergic transmission (Shen and Johnson, 1997; Bagley et al., 1999; Oliet and Poulain, 1999). However, in hippocampus and 


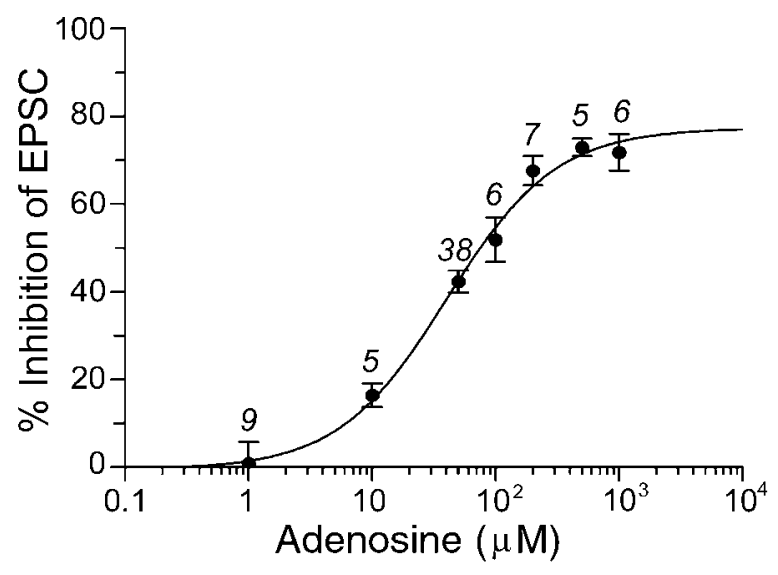

Figure 2. Dose-response curve for adenosine inhibition of evEPSCs. The line represents the computer-generated fit to the data according to the equation: $Y=\min _{\text {resp }}+\left\{\left(\max _{\text {resp }}-\min _{\text {resp }}\right) /\left(1+10\left[\left(\log \mathrm{EC}_{50}-\right.\right.\right.\right.$ $\log \mathrm{AD}) \times H])\}$, with $\min _{\text {resp }}=0 \%$, max $_{\text {resp }}=77.3 \%, \mathrm{EC}_{50}=39.9 \mu \mathrm{M}$, $\mathrm{AD}=$ adenosine concentration in micromolar, and Hill slope, $H=0.98$. The numbers indicate the number of cells recorded.

septal nucleus, adenosine inhibits glutamatergic transmission but not GABAergic transmission (Yoon and Rothman, 1991; Hasuo et al., 1992). Therefore, we tested the effect of adenosine on glutamatergic evEPSCs and GABAergic evIPSCs. Pharmacologically isolated evEPSCs, recorded in the presence of BMI (20 $\mu \mathrm{M})$, were reduced by adenosine $(50 \mu \mathrm{M})$ by $42.35 \pm 2.56 \%$ in 38 of 48 neurons tested (Fig. $1 A$ ). In the remaining 10 neurons, the evEPSCs were unaffected by adenosine $(0.3 \pm 2.04 \%)$. GABAergic evIPSCs, recorded during bath application of DNQX and $\operatorname{APV}\left(V_{\mathrm{h}}=-45\right.$ to $\left.-40 \mathrm{mV}\right)$, were also reduced by adenosine $(50$ $\mu \mathrm{M}$ ) by $56.4 \pm 7.1 \%$ in seven of nine neurons tested (Fig. $1 B$ ). Moreover, as shown in Figure 2, adenosine reduced the amplitude of the glutamatergic evEPSCs in a dose-dependent manner with $\max _{\text {resp }}=77.3 \%$ and $\mathrm{EC}_{50}=39.9 \mu \mathrm{M}$, which are similar to those previously found in the hippocampus and hypothalamus (Dunwiddie and Hoffer, 1980; Oliet and Poulain, 1999).

Adenosine inhibits CNS neurons by activating a G-proteinactivated inwardly rectifying $\mathrm{K}^{+}$current (GIRK) (Trussell and Jackson, 1985), and in particular, this current is activated by adenosine in LDT neurons (Rainnie et al., 1994). Activation of the GIRK current might result in a conductance shunt of the evEPSC and hence contribute to the reduction of the evEPSC amplitude. Consequently, we examined 79 LDT neurons for the effects of adenosine on the isolated evEPSC and on activation of postsynaptic GIRK currents, the latter by measuring either activation of an outward current $\left(V_{\mathrm{h}}=-60 \mathrm{mV}\right.$ ) (see Fig. $6 A$ ) or increase in the amplitude of currents obtained during a voltage ramp command from -100 to $-35 \mathrm{mV}, 10 \mathrm{mV} / \mathrm{sec}$ (see Fig. $6 C_{1}$ ). Adenosine activated postsynaptic GIRK currents in $57 \%$ of the LDT neurons recorded. In $87 \%$ of these neurons, adenosine also induced inhibition of the evEPSC. Thus, in $13 \%$ of the neurons showing an adenosine-mediated increase in postsynaptic GIRK current, there was no adenosine-mediated inhibition of the evEPSC. Furthermore, reduction in the amplitude of the evEPSC was observed in $71 \%$ of the neurons that did not show adenosine postsynaptic effects, supporting the argument that the inhibition of the evEPSCs can be mediated independently of the postsynaptic effects.

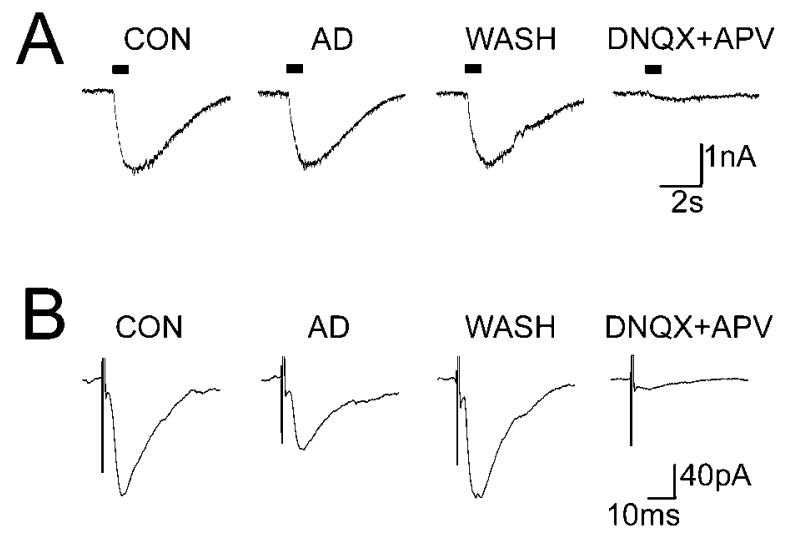

(in the presence of $\mathrm{BaCl}_{2}$ )

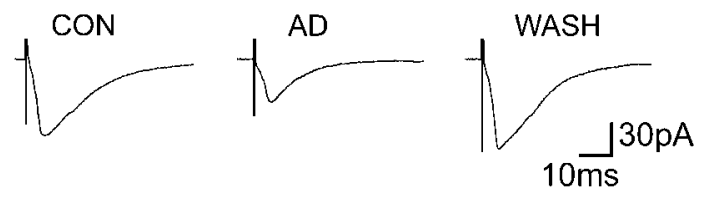

Figure 3. Modulation of glutamatergic transmission occurs independently of adenosine postsynaptic effects. $A$, Adenosine does not alter postsynaptic response to glutamate. Glutamate-evoked currents, elicited by exogenous glutamate $(1 \mathrm{mM})$ pressure injected on the recording neuron $\left(V_{\mathrm{h}}=-60 \mathrm{mV}\right)$, are unaffected by bath application of adenosine but are blocked by application of DNQX $(20 \mu \mathrm{M})$ and APV (100 $\mu \mathrm{M})$. The duration of each glutamate injection $(1 \mathrm{sec})$ is indicated by the black bar above each current trace. $B$, In the same neuron, adenosine reversibly decreases evEPSC amplitude. Application of DNQX and APV eliminates the evEPSCs. $C$, Adenosine inhibition of the evEPSCs is independent of both presynaptic and postsynaptic GIRK activation. In another neuron, adenosine still reduces evEPSC amplitude in the presence of $2 \mathrm{mM} \mathrm{BaCl}_{2}$. Each evEPSC current trace is the average of 10 evEPSCs $\left(V_{\mathrm{h}}=-60 \mathrm{mV}\right)$.

\section{Adenosine reduces the evoked EPSC amplitude without changing the postsynaptic response to exogenous glutamate application}

In the absence of a GIRK-mediated shunt, the reduction in the evEPSC amplitude in the presence of adenosine could be caused by (1) changes in the amount of neurotransmitter released presynaptically or (2) changes in the responsiveness of postsynaptic glutamate receptors, or both. Adenosine inhibits glutamatergic transmission mainly through an activation of presynaptic adenosine receptors (for review, see Ribeiro, 1995; Brundege and Dunwiddie, 1997). However, recent studies have raised the possibility that adenosine can directly attenuate postsynaptic NMDA currents in hippocampal projection neurons and retinal bipolar cells (de Mendonca et al., 1995; Costenla et al., 1999). To determine whether the inhibitory effect of adenosine on the evEPSC in LDT neurons might result from a change in the postsynaptic response to glutamate, we compared the effect of adenosine on currents evoked by pressure-ejected glutamate (see Materials and Methods) with the effect of adenosine on evEPSC.

At the holding potential of $-60 \mathrm{mV}$, transient $(0.8-1.2 \mathrm{sec})$ application of glutamate $(1 \mathrm{~mm})$ evoked an inward current ranging between 0.95 and $2.2 \mathrm{nA}$ in LDT neurons $(n=4)$. In four of four neurons tested, the glutamate-evoked currents were unaffected by adenosine $(50 \mu \mathrm{M})$ (Fig. $3 A)$, whereas the amplitude of 

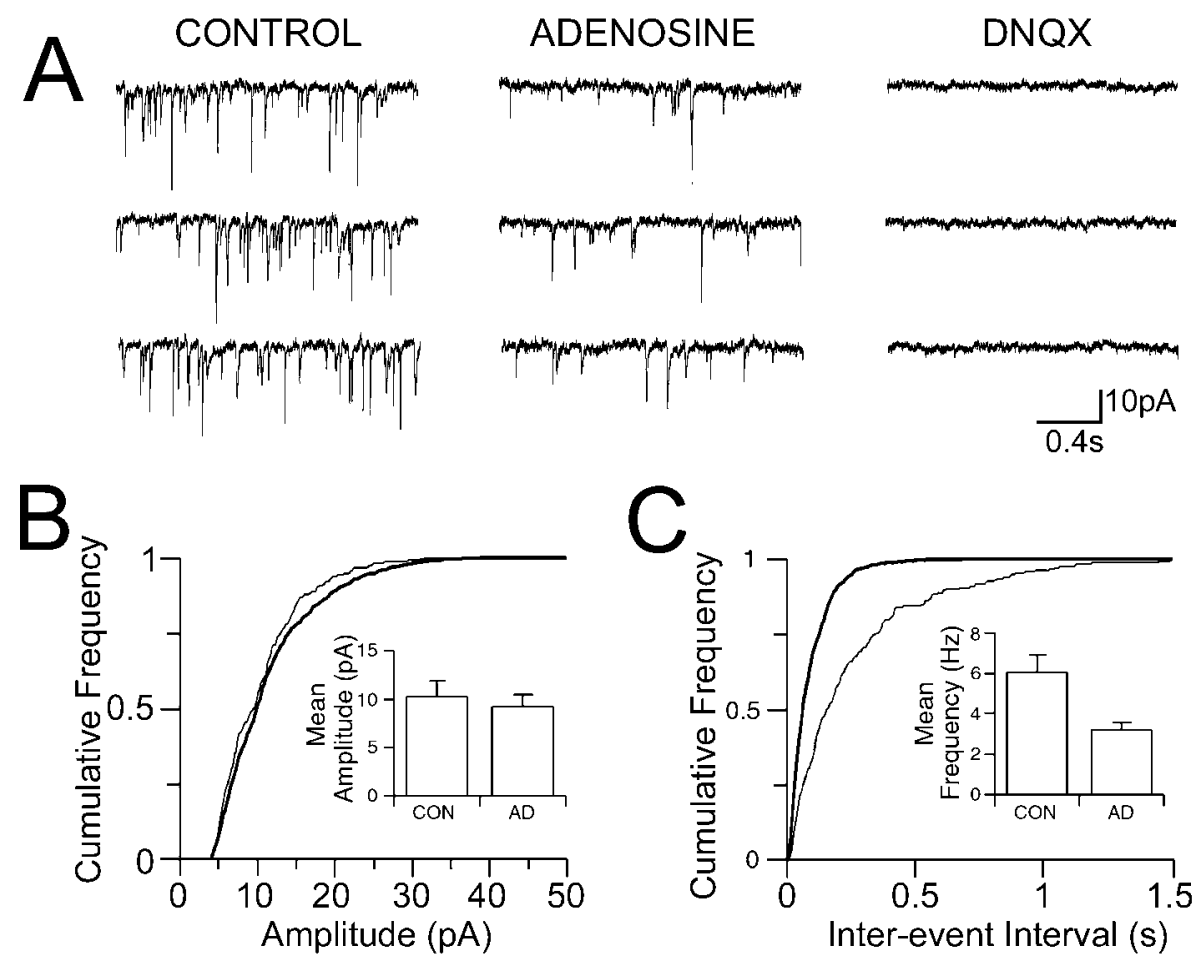

Figure 4. Adenosine reduces glutamatergic mEPSC frequency without affecting mEPSC amplitude. $A$, Consecutive traces (2 sec each) recorded at $V_{\mathrm{h}}=-60 \mathrm{mV}$, showing typical $\mathrm{mEPSC}$ in control ACSF (left) and during the applications of adenosine (50 $\mu \mathrm{M}$; middle) and DNQX $(20 \mu \mathrm{M} ;$ right $)$. Adenosine produces a decrease in frequency of mEPSC, and DNQX blocks the mEPSCs. $B, C$, Cumulative distribution plots of mEPSC amplitude and inter-event interval before (thick line) and during (thin line) adenosine application for the experiment shown in $A$. The cumulative plots show that adenosine does not induce a significant variation of the mEPSC amplitude $(p>0.1, \mathrm{~K}-\mathrm{S}$ test; events analyzed $=685$ in control and 232 with adenosine), whereas it does induce a shift toward the right in the distribution of inter-event intervals $(p<0.001, \mathrm{~K}-\mathrm{S}$ test $)$, indicating a decrease in mEPSC frequency. The mean mEPSC amplitude and frequency data pooled from nine neurons are represented in the two histograms $(B$, $C$, insets). Adenosine reduces mean mEPSC frequency $(6.18 \pm 0.79 \mathrm{~Hz}$ in control; $3.21 \pm 0.34 \mathrm{~Hz}$ in adenosine; $p=0.0015$, paired $t$ test) without significant effect on the mean mEPSC amplitude $(10.25 \pm 1.44 \mathrm{pA}$ in control; $9.35 \pm 1.15 \mathrm{pA}$ with adenosine; $p=0.066$, paired $t$ test). the evEPSC was reduced by $47.9 \pm 2.2 \%$ (Fig. $3 B$ ). Both the evEPSCs and the currents elicited by glutamate injection were sensitive to DNQX $(20 \mu \mathrm{M})$ and APV $(100 \mu \mathrm{M})$ applied in the bath $(n=3)$, indicating that both were mediated through activation of postsynaptic glutamatergic receptors (Fig. $3 A, B$ ). A direct inhibitory effect of adenosine on the postsynaptic glutamate receptors would seem unlikely, although a specific effect at electrotonically distant glutamate receptors cannot be excluded.

\section{Adenosine reduces the frequency of mEPSPs}

To further investigate the location of adenosine receptors, we next analyzed the action of adenosine on the amplitude and frequency of glutamatergic spontaneous mEPSCs. These spontaneous unitary events were recorded at a holding potential of -60 $\mathrm{mV}$ and in the presence of TTX $(1 \mu \mathrm{M})$, which completely abolished evoked synaptic transmission. The frequency of mEPSCs ranged between 3.18 and $11.23 \mathrm{~Hz}$ under control conditions $(n=9)$, whereas the mean amplitude varied between 5 and 19.68 pA (191-674 events for each cell). Application of DNQX (20 $\mu \mathrm{M})$ completely blocked the mEPSCs, suggesting mediation by glutamate (Fig. 4A). In five of the nine neurons recorded, occasional mIPSCs were observed that were sensitive to BMI $(20 \mu \mathrm{M} ; n=$ 2 ), suggesting mediation by postsynaptic $\mathrm{GABA}_{\mathrm{A}}$ receptors. However, the frequency of mIPSCs was typically observed to be between 0.1 and $0.8 \mathrm{~Hz}$ under control conditions, which was too low for adequate analysis of amplitude and inter-event interval distribution. We therefore focused on adenosine modulatory effects of spontaneous mEPSCs.

When adenosine $(50 \mu \mathrm{M})$ was added to the bathing solution, the spontaneous mEPSC activity was reduced in all neurons recorded $(n=9)$ (Fig. 4A). We examined the amplitude and inter-event interval distributions of the spontaneous mEPSCs. The results of a representative neuron are shown in Figure $4, B$ and $C$. No significant difference was found between the amplitude distribution obtained under control conditions and that obtained in the presence of adenosine $(p>0.1, \mathrm{~K}-\mathrm{S}$ test; $n=9)$. Moreover, the amplitude of the spontaneous mEPSC was unaffected in five of the nine recorded neurons in which adenosine activated a postsynaptic GIRK conductance (17.95 $\pm 12 \mathrm{nS})$. In contrast, application of adenosine did affect the cumulative inter-event interval distribution of the mEPSC, producing a significant rightward shift of the curve ( $p<0.01, \mathrm{~K}-\mathrm{S}$ test; $n=9)$, reflecting a decrease of mEPSC frequency. Pooled data from nine recorded neurons are represented in Figure 4, $B$ and $C$ (insets), and show that adenosine decreases the mean mEPSC frequency $(6.18 \pm$ $0.79 \mathrm{~Hz}$, in control; $3.21 \pm 0.34 \mathrm{~Hz}$, with adenosine; $p=0.0015$, paired $t$ test) in the absence of a significant change in the mean mEPSC amplitude $(10.25 \pm 1.44 \mathrm{pA}$, in control; $9.35 \pm 1.1 \mathrm{pA}$, with adenosine; $p=0.066$ paired $t$ test).

Modifications of miniature synaptic current frequency, in the absence of changes in amplitude distribution, most likely reflect a change in neurotransmitter release probability (Redman, 1990). Our findings are therefore consistent with a presynaptic location for the adenosine receptors, the activation of which results in an inhibition of glutamate release. Because the amplitude distributions of the mEPSCs were not significantly affected, it is unlikely that postsynaptic glutamate receptors are directly modulated by adenosine.

\section{Does activation of GIRK current mediate the presynaptic inhibition?}

One of the possible mechanisms by which adenosine can inhibit evoked glutamatergic transmission through presynaptic $A_{1}$ receptor activation is by activating the same GIRK current that adenosine activates postsynaptically, thus shunting the presynaptic action potential and decreasing the voltage-dependent $\mathrm{Ca}^{2+}$ entry (for review, see Brundege and Dunwiddie, 1997). To determine whether the inhibitory effect of adenosine on the evoked EPSC was mediated by presynaptic activation of GIRK, we tested the effect of adenosine in the presence of $2 \mathrm{mM} \mathrm{BaCl}_{2}$, which is known to completely block the GIRK conductance activated by adenosine (Gerber et al., 1989; Birnstiel et al., 1992). Barium did 

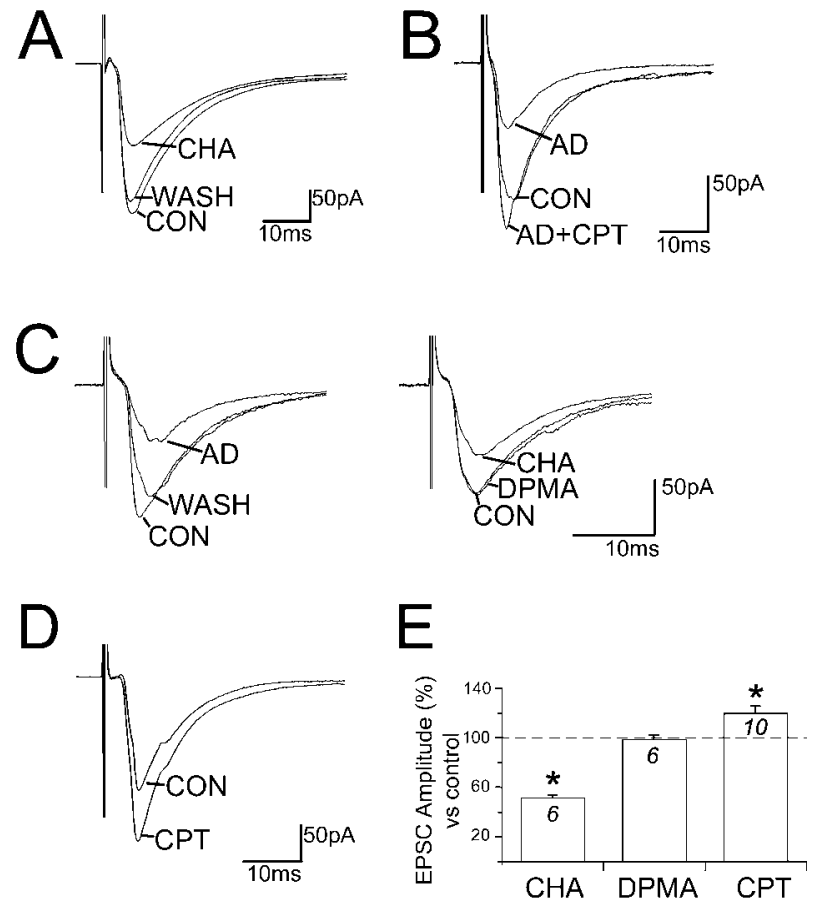

Figure 5. Exogenous and endogenous adenosine inhibit the evEPSCs through activation of $\mathrm{A}_{1}$ receptors. $A$, Application of the $\mathrm{A}_{1}$ receptor agonist CHA (100 nM) reduces the evEPSC amplitude. $B$, The evEPSC inhibition mediated by $50 \mu \mathrm{M}$ adenosine $(A D)$ is removed by the $\mathrm{A}_{1}$ receptor antagonist CPT $(200 \mathrm{nM})$. $C$, A neuron sensitive to adenosine (left) does not respond to the $\mathrm{A}_{2}$ agonist DPMA (10 nM) but does respond to further application of CHA (right). D, Application of CPT alone induces an increase in the evEPSC amplitude. $E$, Summary of the effects on the evEPSC. The histogram shows the mean \pm SE of the evEPSC peak amplitude during applications of CHA, DPMA, and CPT expressed as a percentage of their respective evEPSC amplitude in control. Only adenosine-sensitive cells were considered. The numbers indicate the number of cells recorded: ${ }^{*} p<0.01$ versus evEPSC amplitude under control conditions; paired $t$ test.

not block adenosine $(50 \mu \mathrm{M})$ inhibition of the evEPSC in any neurons tested (Fig. $3 C$ ). In the presence of $\mathrm{BaCl}_{2}$, adenosine still reduced evEPSC amplitude by $53.8 \pm 7.3 \%(n=6)$, compared with a reduction of $42.35 \pm 2.56 \%$ by adenosine $(50 \mu \mathrm{M} ; n=38)$ in control conditions. The activation of presynaptic GIRK is therefore unlikely to contribute to the adenosine-mediated inhibition of the evEPSC.

\section{Adenosine inhibits evoked excitatory inputs via activation of $A_{1}$ receptors}

In the CNS, the inhibitory effect of adenosine on cellular and synaptic activity appears to be primarily mediated by $A_{1}$ receptors (for review, see Greene and Haas, 1991; Brundege and Dunwiddie, 1997). Adenosine reduces the activity of LDT neurons through direct activation of postsynaptic $\mathrm{A}_{1}$ receptors (Rainnie et al., 1994). Here we have shown an additional indirect inhibition by reduction of excitatory inputs; however, the subtype of the receptor involved in this effect was unknown.

We studied the effects of the $A_{1}$ receptor agonist CHA (100 $\mathrm{nM})$ for the selective activation of $\mathrm{A}_{1}$ receptors $\left(\mathrm{EC}_{50}=1-2 \mathrm{nM}\right.$ at $\mathrm{A}_{1}$ receptors; $\mathrm{EC}_{50}=450-1000 \mathrm{nM}$ at $\mathrm{A}_{2}$ receptors) (Bruns et al., 1986). The effects of application of $\mathrm{CHA}$ on evEPSCs were identical in character to those of adenosine $(n=9)$ (Fig. $5 A, E)$. In six of these neurons tested with CHA, the evEPSC amplitude was reduced by $59.8 \pm 6.3 \%$ and by $48.8 \pm 2.7 \%$ with adenosine. In the remaining three neurons, the evEPSCs were unaffected by either CHA or adenosine.

In a second set of experiments, we antagonized adenosine inhibition of the evEPSCs with the $\mathrm{A}_{1}$ receptor antagonist CPT ( $K_{i}=10.9 \mathrm{~nm}$ at $\mathrm{A}_{1}$ receptors; $K_{i}=1440 \mathrm{~nm}$ at $\mathrm{A}_{2}$ receptors) (Bruns, 1981). Application of CPT (200 nм; $n=10)$ completely antagonized the effects of adenosine $(50 \mu \mathrm{M})$, which elicited a reduction of evEPSC by $48.7 \pm 6.9 \%$. During the course of these experiments it was noted that compared with control conditions, CPT caused a significant increase in the evEPSC amplitude $(11.7 \pm 6.93 \% ; p=0.039$, paired $t$ test), consistent with removal of a tonic inhibition by endogenous adenosine (Fig. $5 B$ ). Taken together, these results suggest that adenosine inhibits evoked excitatory transmission in the LDT through activation of presynaptic $A_{1}$ receptors. However, the increase in evEPSC amplitude observed in the presence of the $A_{1}$ receptor antagonist might be caused, at least in part, by the activation of additional adenosine receptor subtypes.

\section{Are adenosine $A_{2}$ receptors involved in the modulation of the evoked EPSC?}

Although activation of the $A_{1}$ receptors induces inhibitory effects on cellular and synaptic activity, activation of $A_{2}$ receptors induces presynaptic and postsynaptic excitatory responses (Palmer and Stiles, 1995). In several areas of the CNS, $A_{1}$ and $A_{2}$ receptors are coexpressed, for instance, in the striatum (Brown et al., 1990) and in the hippocampus (Li and Henry, 1998). Enhancement of neurotransmitter release by adenosine is evident only when $A_{1}$ receptors are blocked. On the basis of these observations, the increased evEPSC amplitude that we observed with $\mathrm{CPT}$ in the presence of adenosine (Fig. $5 B$ ) might have resulted from the coactivation of $\mathrm{A}_{2}$ receptors.

We examined this possibility by testing the activation of $\mathrm{A}_{2}$ receptors with the selective $\mathrm{A}_{2}$ receptor agonist, DPMA. To selectively activate the $A_{2}$ rather than the $A_{1}$ receptors, we used DMPA at a concentration of $10 \mathrm{~nm}\left(K_{i}=142 \mathrm{nM}\right.$ at $\mathrm{A}_{1}$ receptors; $K_{i}=4.4 \mathrm{~nm}$ at $\mathrm{A}_{2}$ receptors) (Bridges et al., 1988), a concentration that elicited an $\mathrm{A}_{2}$-dependent enhancement of the evEPSC amplitude in hippocampal slices in vitro (Kessey and Mogul, 1998). Applications of DPMA did not alter the amplitude or the duration of the evEPSC $(98.9 \pm 1.25 \%$ of the control amplitude; $n=6$ ) (Fig. 5C,E), nor did it affect postsynaptic membrane potential or resistance. However, in the same cells, adenosine inhibited the evEPSC by $41.8 \pm 4.4 \%$. These findings suggest that $\mathrm{A}_{2}$ receptor activation does not mediate adenosine effects on evEPSC or excitability of LDT neurons.

\section{Excitatory synaptic transmission is under inhibitory control by endogenous adenosine}

Application of adenosine $A_{1}$ receptor antagonists induces excitatory presynaptic and postsynaptic responses compatible with a removal of the inhibitory tone of endogenous adenosine (Dunwiddie et al., 1981; Greene et al., 1985; Haas and Greene, 1988). In the LDT, application of CPT induces an increase in neuronal activity as well as an increase in the amplitude of hyperpolarization-activated current $\left(I_{\mathrm{h}}\right)$, which is reduced by adenosine (Rainnie et al., 1994). To test the possibility that glutamatergic transmission could also be under tonic inhibition by endogenous adenosine, we measured the effects of CPT on the glutamatergic evEPSC. In those neurons that were adenosine sensitive, CPT (200 nM) alone induced an increase in the evEPSC 

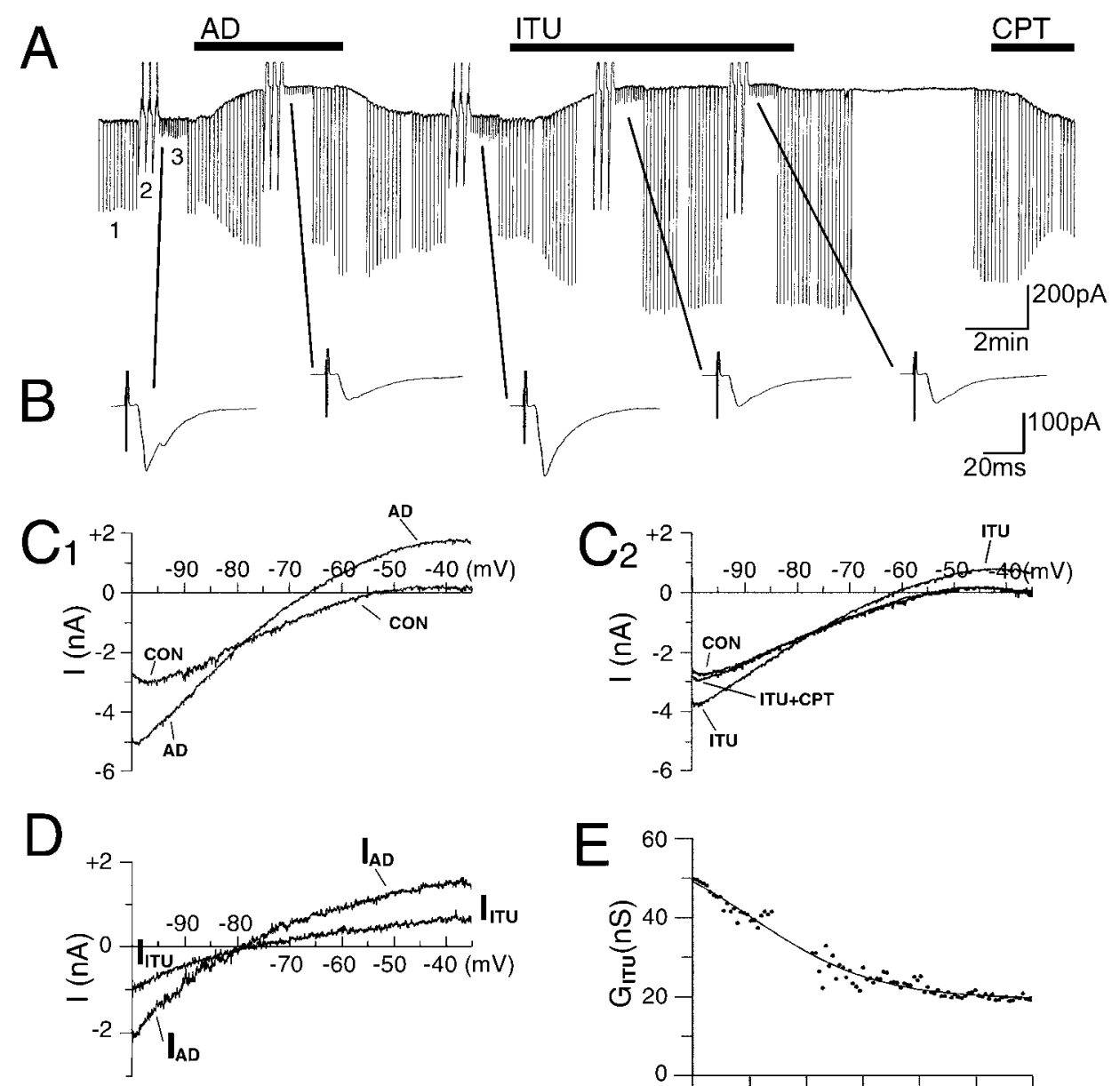
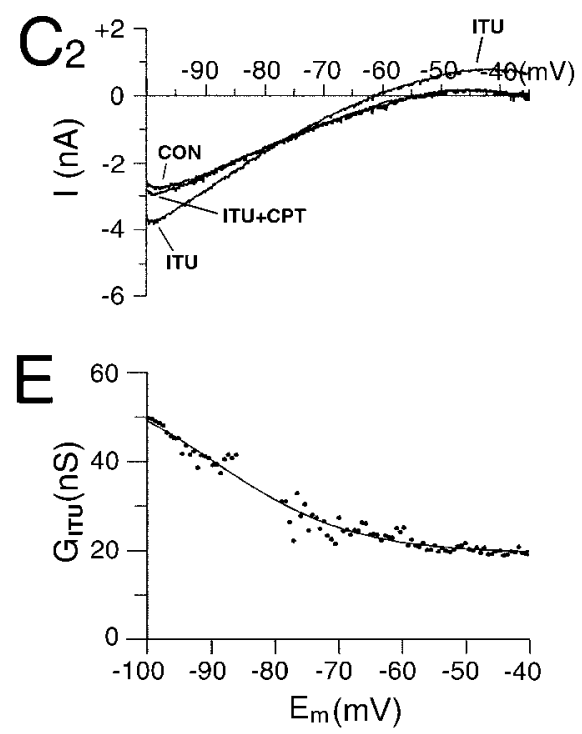

Figure 6. ITU induces postsynaptic activation of an inwardly rectifying $\mathrm{K}^{+}$current and inhibition of the evoked glutamatergic transmission, similar to adenosine. $A$, Currents recorded at $V_{\mathrm{h}}=-60 \mathrm{mV}$. Downward deflections resulted from three different voltage protocol commands indicated by the numbers: 1 , voltage pulses to $-100 \mathrm{mV}(200 \mathrm{msec}$; $0.2 \mathrm{~Hz})$; 2, voltage ramps from -100 to $-35 \mathrm{mV}(10 \mathrm{mV} / \mathrm{sec})$; 3 , stimulation with a bipolar stimulating electrode $(0.3 \mathrm{~Hz})$. All protocols are performed in control ACSF and during applications of adenosine $(A D ; 50 \mu \mathrm{M})$, ITU $(10 \mu \mathrm{M})$, and CPT (200 nM), indicated by black bars above the current traces. Both adenosine and ITU induce increases in the membrane conductance. The outward current elicited by ITU was rapidly blocked by application of CPT. B, evEPSCs recorded during control condition, adenosine, and ITU applications. The evEPSCs are inhibited by both adenosine and ITU. Each current trace is the average of 10 evEPSCs. $C_{1}, C_{2}$, Recordings from another neuron, obtained during the voltage-ramp protocols; each current trace displayed is the average of three consecutive voltage ramps. Adenosine $\left(C_{I}\right)$ and ITU $\left(C_{2}\right)$ increase the membrane slope conductance at all membrane potentials between -100 and $-35 \mathrm{mV}$. The effect of ITU is antagonized by CPT $\left(C_{2}\right)$. D , Current-voltage relationships of adenosine $\left(I_{A D}\right)$ and ITU $\left(I_{I T U}\right)$ evoked currents, calculated by digital subtraction $\left(I_{\mathrm{AD}}=\right.$ $\mathrm{AD}-\mathrm{CON})$ and $\left(I_{\mathrm{ITU}} 61 \mathrm{ITU}-\mathrm{CON}\right)$ of the currents displayed in $C_{1}$ and $C_{2} . I_{\mathrm{AD}}$ and $I_{\mathrm{ITU}}$ show the same reversal potential $(-81 \mathrm{mV})$ and the same voltage-dependent slope conductance, consistent with adenosine and ITU-mediated inwardly rectifying $\mathrm{K}^{+}$current activations. $E$, ITU chord conductance $\left(G_{I T U}\right)$ as a function of membrane potential $\left(E_{m}\right) \cdot G_{\text {ITU }}$ is obtained from the values of $I_{\text {ITU }}$ shown in $D\left(G_{\text {ITU }}=\right.$ $I_{\text {ITU }} /\left(E_{\mathrm{m}}-E_{\text {reversal }}\right)$ and is fit to the Boltzmann equation (line) $G_{\mathrm{ITU}}=G_{\mathrm{ITU}(\min )}+\left(G_{\mathrm{ITU}(\max )}\right.$ $\left.-G_{\text {ITU(min) })}\right) /\left\{1+\exp \left[\left(E_{\mathrm{m}}-E_{1 / 2}\right) / k\right]\right\}$, with $G_{\mathrm{ITU}(\max )}=56 \mathrm{nS}, G_{\mathrm{ITU}(\min )}=19.6 \mathrm{nS}, E_{1 / 2}=$ $-87 \mathrm{mV}$, and $k=9.7 \mathrm{mV}$. amplitude by $20 \pm 5.9 \%(n=10)$ (Fig. $5 D, E)$. In addition, the holding currents of five of these neurons were reduced through the application of CPT by $24.8 \pm 11.5 \mathrm{pA}$, which is similar to the reduction previously reported for LDT neurons (Rainnie et al., 1994). These data confirm that in the LDT, the endogenous, extracellular, adenosine concentration is sufficiently high to induce a physiologically measurable inhibition of synaptic glutamate release. In the hypothalamic supraoptic nucleus, CPT only potentiates glutamatergic evEPSCs after train stimulation of 200 sec duration (Oliet and Poulain, 1999). In contrast, in the LDT, electrophysiologically significant basal release of adenosine is appreciable.

\section{Adenosine kinase inhibitor 5-iodotubercidin increases endogenous adenosine levels}

Adenosine is primarily formed from the breakdown of ATP within cells and is transported across the cell membrane by equilibrative transporters (Geiger and Fyda, 1991; Thorn and Jarvis, 1996). Thus, any increase in the intracellular adenosine concentration is likely to be reflected as an increase of adenosine in the extracellular space (Brundege and Dunwiddie, 1996). Intracellular adenosine metabolism occurs through phosphorylation by adenosine kinase and deamination by adenosine deami- nase. Blockers of these two enzymes can induce an increase in the intracellular adenosine level and consequently extracellular adenosine levels (Brundege and Dunwiddie, 1997). Inhibitors of adenosine kinase, more than inhibitors of adenosine deaminase, increase extracellular adenosine levels in hippocampal, spinal cord, and cortical slices under control conditions (Pak et al., 1994; Lloyd and Fredholm, 1995; Golembiowska et al., 1996; White, 1996), consistent with the higher affinity of adenosine kinase for adenosine (Arch and Newsholme, 1978). The adenosine kinase inhibitor ITU can decrease neuronal activity in hippocampal and cortical slices by increasing extracellular adenosine levels (Pak et al., 1994; White, 1996). Consequently, we examined the effects of ITU in the LDT. Neurons sensitive to adenosine responded to ITU application $(n=9)$ in a manner indistinguishable from adenosine. Application of ITU $(10 \mu \mathrm{M})$ induced an increase in the membrane conductance (Fig. $6 A$ ) shown by both (1) activation of an outward current $\left(V_{\mathrm{h}}=-60 \mathrm{mV}\right)$ and (2) an increase in the amplitude of the current evoked by hyperpolarizing voltage step commands to $-100 \mathrm{mV}$. The response to ITU appeared in 3-6 min, whereas its recovery was only observed after $>45 \mathrm{~min}$ of drug washout. However, ITU effects were rapidly blocked when the $\mathrm{A}_{1}$ receptor antagonist CPT (200 nM) was applied (Fig. 6A). 

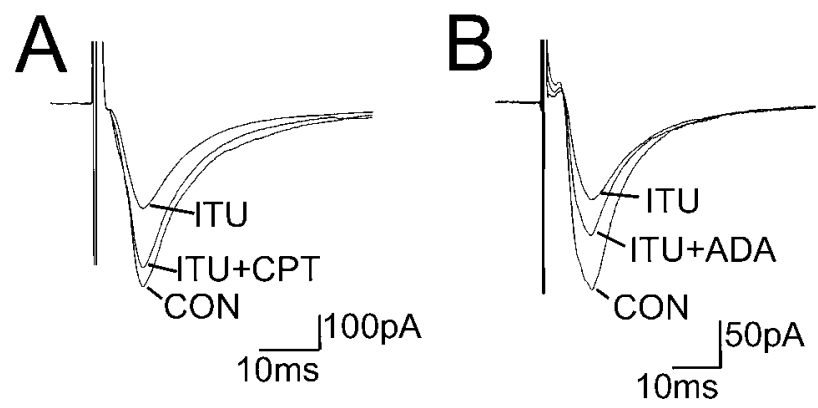

Figure 7. The inhibitory effect of ITU on the evEPSCs can be blocked by $\mathrm{A}_{1}$ receptor antagonist $\mathrm{CPT}$ or by adenosine deaminase. $A$, CPT (200 nM) antagonized the inhibition of the evEPSC by ITU. $B$, In another neuron, adenosine deaminase $(A D A)(0.8 \mathrm{IU} / \mathrm{ml})$ partially removed the inhibitory effect of ITU. Each current trace is the average of 10 evEPSCs $\left(V_{\mathrm{h}}=-60 \mathrm{mV}\right)$.

Three neurons that were insensitive to adenosine were also insensitive to ITU.

To investigate whether the responses to adenosine and ITU were mediated by activation of the same GIRK, we compared the voltage sensitivity and reversal potential of the current evoked by adenosine $\left(I_{\mathrm{AD}}\right)$ with those evoked by ITU $\left(I_{\mathrm{ITU}}\right)$. Currents obtained during a voltage ramp command from -100 to $-35 \mathrm{mV}$ $(10 \mathrm{mV} / \mathrm{sec})$ were recorded before and during adenosine application (Fig. $6 C_{1}$ ), and before and during ITU application (Fig. $6 C_{2}$ ). These recordings were used to obtain current-voltage relationships for $I_{\mathrm{AD}}$ and $I_{\mathrm{ITU}}$ by digitally subtracting the currents recorded under control conditions from those recorded during drug applications (Fig. 6D). Current-voltage relationships obtained from five neurons showed that $I_{\text {ITU }}$ had the same rectification properties and an identical reversal potential as $I_{\mathrm{AD}}\left(E_{\mathrm{ITU}}=\right.$ $-82.04 \pm 9.7 \mathrm{mV} ; E_{\mathrm{AD}}=-82.6 \pm 3.87 \mathrm{mV}$ ) compared with adenosine-mediated GIRK (Rainnie et al., 1994). Moreover, $I_{\text {ITU }}$ was blocked by CPT (200 nM; $n=4)\left(\right.$ Fig. $\left.6 C_{2}\right)$. The ITU chord conductance $\left(G_{\text {ITU }}\right)$ as a function of membrane potential $\left(E_{\mathrm{m}}\right)$, shown in Figure $6 E$, was derived from the $I_{\text {ITU }}$ voltage relationship. A curve constrained by the Boltzmann equation (Fig. 6, legend) with half-activated potential, $E_{1 / 2}=-87 \mathrm{mV}$, and a slope factor, $k=9.7 \mathrm{mV}$, was then fit to the data. These values were similar to those reported in LDT neurons for the adenosine chord conductance (Rainnie et al., 1994).

\section{ITU inhibits the evEPSC}

We next examined the effect of ITU on the evEPSC. Similar to adenosine, application of ITU inhibited evoked excitatory transmission (Figs. 6B,7). evEPSCs were recorded from eight neurons, and the response to exogenous adenosine and ITU application was examined. In six neurons, adenosine reduced the evEPSC by $51.1 \pm 3.23 \%$, and ITU reduced the evEPSC by $49 \pm$ $4 \%$. In the remaining two neurons, the evEPSCs were insensitive to both adenosine and ITU application. From the dose-response relationship characterizing the effect of exogenous adenosine on the evEPSC amplitude (Fig. 2), we can estimate that the inhibitory effect of ITU on the evEPSC is comparable with an application of exogenous adenosine of $\sim 50-100 \mu \mathrm{M}$. In addition, the evEPSC inhibition by ITU could be completely antagonized by the $\mathrm{A}_{1}$ receptor antagonist CPT (200 nM; $\left.n=3\right)$ (Fig. $\left.7 A\right)$ and by application of the enzyme adenosine deaminase $(0.8 \mathrm{IU} / \mathrm{ml} ; n=$ 2) (Fig. 7B).

These data, taken together, show that in an in vitro preparation,
LDT neurons are tonically inhibited by extracellular endogenous adenosine and that the level of endogenous adenosine can be dramatically altered by manipulating the adenosine kinase responsible for adenosine metabolism.

\section{DISCUSSION}

In summary, adenosine reduces both glutamate- and GABAmediated evEPSCs and evIPSCs recorded from neurons of the LDT nucleus. Moreover, by focusing on the excitatory input, we found that adenosine directly inhibits glutamatergic transmission by activating presynaptic adenosine $A_{1}$ receptors. In addition, a reduction of adenosine catabolism by an inhibition of adenosine kinase results in an activation of presynaptic and postsynaptic $A_{1}$ receptors comparable, in both character and degree, with activation by exogenous adenosine $(50-100 \mu \mathrm{M})$.

\section{Presynaptic inhibition}

Evidence for a presynaptic locus of the adenosine-mediated inhibition of the glutamate transmission is based on several independent results. First, the adenosine-mediated inhibition of glutamatergic evEPSCs was not associated with alterations in the postsynaptic sensitivity of glutamate receptors. Second, adenosine reduced the frequency, but not amplitude, of spontaneous glutamatergic mEPSCs. Third, the presynaptic effect of adenosine could occur independently of a postsynaptic adenosine effect.

The presynaptic mechanism through which adenosine inhibits the glutamatergic release remains to be determined. However, the inhibition of the evEPSC by adenosine was maintained in the presence of $2 \mathrm{mM} \mathrm{BaCl}_{2}$, which is known to block the postsynaptic GIRK conductance activated by adenosine (Gerber et al., 1989; Birnstiel et al., 1992). It is probable, therefore, that adenosine does not inhibit glutamatergic evEPSCs by activating a GIRK conductance in the presynaptic terminal. This result is consistent with the literature, which does not support a presynaptic GIRK activation as a primary mechanism by which adenosine inhibits neurotransmitter release (Dunwiddie and Miller, 1993; Brundege and Dunwiddie, 1997). It is more likely that the inhibition of excitatory transmission in the LDT nucleus occurs via the modulation of presynaptic calcium channels. Adenosine is known to (1) inhibit voltage-dependent $\mathrm{Ca}^{2+}$ channels (Dolphin et al., 1986; Scholz and Miller, 1991; Mogul et al., 1994) and (2) reduce the evEPSC amplitude by inhibiting the presynaptic calcium fluxes in hippocampus and striatum (Wu and Saggau, 1994; Ambrosio et al., 1997). Alternatively, or in combination, adenosine may also act presynaptically to inhibit glutamate release at a point downstream from $\mathrm{Ca}^{2+}$ entry, as shown in the hippocampus where adenosine still reduces spontaneous synaptic activity when $\mathrm{Ca}^{2+}$ entry is blocked (Scanziani et al., 1992; Scholz and Miller, 1992). Recently, a reduction of glutamatergic and GABAergic transmission has been shown after presynaptic inhibition of adenylate cyclase-protein kinase A cascade (Tzounopoulos et al., 1998; Bagley et al., 1999). Activation of $\mathrm{A}_{1}$ receptors also inhibits adenylate cyclase activity, which mediates the reduction of presynaptic GABA release in the periacqueductal gray neurons (Bagley et al., 1999) and may contribute to the presynaptic inhibition of glutamate release observed in the LDT nucleus.

\section{Endogenous adenosine}

We provide direct evidence for the presence of a basal endogenous adenosine level in the LDT nucleus that can tonically activate adenosine $\mathrm{A}_{1}$ receptors. Hence, application of CPT potentiated the stimulus-evoked glutamatergic EPSC. This is 
compatible with a removal of an endogenous inhibitory adenosine tone on the glutamatergic input to the LDT and may represent the presynaptic mechanism contributing to the CPT-induced increase in network excitability observed with extracellular recording in the LDT (Rainnie et al., 1994).

It has been reported that intracellular catabolism of adenosine may directly affect the extracellular concentration of adenosine through the adenosine equilibrative facilitated transporter system (Geiger and Fyda 1991; Pak et al., 1994; Brundege and Dunwiddie, 1996, 1997). Thus, if catabolism is slowed, then an increase in intracellular adenosine may be reflected by an increase in extracellular adenosine. Of the enzymes that catabolize adenosine, adenosine kinase has the highest affinity (Arch and Newsholme, 1978) and thus, under baseline conditions, is most likely to affect the rate of adenosine catabolism (Lloyd and Fredholm, 1995). The present study suggests that when adenosine kinase activity is reduced with ITU, extracellular adenosine levels dramatically increase to give an adenosine-mediated electrophysiological response approximately equal to application of exogenous adenosine at a concentration between 50 and $100 \mu \mathrm{M}$. In addition to being a potent adenosine kinase blocker, ITU is also known to inhibit the equilibrative adenosine transporter (Davies and Cook, 1995). Nevertheless, it is unlikely that ITU induces extracellular adenosine accumulation by blocking adenosine reuptake. First, prolonged application of the adenosine transport blockers NBTI (5 $\mu \mathrm{M}, n=4 ; 30 \mu \mathrm{M}, n=6$ ) and dipyridamole $(5 \mu \mathrm{M} ; n=4)$ does not induce any presynaptic or postsynaptic effects in any of the adenosine-sensitive LDT neurons tested. Second, presynaptic and postsynaptic effects of ITU occur in the first $10 \mathrm{~min}$ of its application, whereas adenosine transport inhibitors cause a slow and gradual accumulation of extracellular adenosine (Brundege and Dunwiddie, 1997; Dunwiddie and Diao, 2000). Therefore, it is probable that blockade of adenosine kinase is the major mechanism by which ITU increased extracellular adenosine levels. Moreover, we cannot exclude the possibility that the final extracellular adenosine accumulation, resulting from the adenosine kinase blockade by ITU, may actually be blunted by the additional inhibitory action of ITU on the adenosine transporters.

\section{Adenosine inhibits glutamatergic input to cholinergic LDT neurons}

The LDT nucleus contains a heterogeneous neuronal population of cholinergic and noncholinergic neurons (Kamondi et al., 1992), part of which has been identified as GABAergic (Ford et al., 1995). It has been reported that $60 \%$ of the LDT neurons affected postsynaptically by adenosine were cholinergic (Rainnie et al., 1994). We show that in $87 \%$ of postsynaptically responding neurons, adenosine also reduces evoked glutamatergic transmission, suggesting that cholinergic LDT neurons can be inhibited by activation of both presynaptic and postsynaptic adenosine receptors. In addition, results from the recording of spontaneous mEP$\mathrm{SCs}$, which better represent the total afferent input conserved in the slice, show that adenosine reduces spontaneous glutamatergic mEPSC frequency in all LDT neurons.

Therefore, adenosine presynaptic responses appear to be more a function of the input rather than of the postsynaptic cell type. We can conclude that the glutamatergic afferents to the LDT neurons do not all have presynaptic adenosine receptors, but virtually all LDT neurons appear to receive at least a portion of glutamatergic projection that is sensitive to adenosine.

\section{Functional role of adenosine modulation of the synaptic input in the LDT nucleus}

Exogenous adenosine reduces spontaneous cell firing of action potentials in $100 \%$ of the cells recorded extracellularly in the slice (Rainnie et al., 1994). However, because adenosine inhibits only $80 \%$ postsynaptically (Rainnie et al., 1994), the remaining $20 \%$ of neurons were inhibited solely by a presynaptic action on the glutamatergic input. Thus, it is likely that with respect to isolated spontaneous local circuit inputs conserved in the slice, adenosine presynaptic effects are predominately disfacilitatory, and the overall effect of presynaptic and postsynaptic adenosine action is inhibitory. The caveat remains that in vivo, the state-dependent balance of disfacillitation and disinhibition is ultimately determined by the state-dependent presynaptic activity of the adenosine-sensitive excitatory and inhibitory inputs.

Recent studies in the literature show the presence of a large number of GABAergic neurons in the LDT nucleus; the majority of them give rise to dense local GABAergic innervations (Ford et al., 1995), and analysis of c-Fos expression suggests that they may be active during REM sleep (Maloney et al., 1999). This local GABAergic circuit is a most likely target of our stimulation protocol in vitro. If this is the case, adenosine is likely to inhibit the output of these GABAergic REM-on neurons.

If an adenosine-sensitive, wake-dependent, excitatory activity predominates in vivo, then our data are consistent with a combined presynaptic and postsynaptic inhibitory adenosine tone during waking. This is consistent with the hypothesis that a localized increase in extracellular adenosine in one or both of the cholinergic arousal centers (the LDT/PPT and the BF) (Portas et al., 1997) facilitates the transition from waking to sleep by inhibition of the activity of these neurons (Rainnie et al., 1994). Because a localized increase in extracellular adenosine in the LDT is sufficient to facilitate the transition from waking to sleep (Portas et al., 1997), the control of the extracellular adenosine concentration may be important in the control of the behavioral state. Indeed, sleep deprivation that increases the probability of making the transition from wake to sleep is associated with an increase in endogenous extracellular adenosine in the BF cholinergic arousal center (Porkka-Heiskanen et al., 1997).

We have demonstrated that by reducing the intracellular catabolism of adenosine with an adenosine kinase inhibitor we can significantly increase extracellular levels of adenosine. If this occurs in the cholinergic arousal centers in vivo, then the likelihood of a behavioral state transition from waking to sleep would be increased. Because adenosine catabolism by adenosine kinase may be altered by changes in the intracellular concentrations of adenosine, AMP, ADP, or ATP (Hawkins and Bagnara, 1987; Mimouni et al., 1994; Pelicano et al., 1997), the localized metabolic state of the cholinergic arousal centers could affect the extracellular adenosine concentration and, accordingly, the behavioral state.

\section{REFERENCES}

Alam MN, Szymusiak R, Gong H, King J, McGinty D (1999) Adenosinergic modulation of rat basal forebrain neurons during sleep and waking: neuronal recording with microdialysis. J Physiol (Lond) 521:679-690

Ambrosio AF, Malva JO, Carvalho AP, Carvalho CM (1997) Inhibition of N-, P/Q- and other types of $\mathrm{Ca}^{2+}$ channels in rat hippocampal nerve terminals by the adenosine $\mathrm{A}_{1}$ receptor. Eur $\mathrm{J}$ Pharmacol 340:301-310.

Arch JR, Newsholme EA (1978) The control of the metabolism and the hormonal role of adenosine. Essays Biochem 14:82-123.

Bagley EE, Vaughan CW, Christie MJ (1999) Inhibition by adenosine 
receptor agonists of synaptic transmission in rat periaqueductal grey neurons. J Physiol (Lond) 516:219-225.

Basheer R, Porkka-Heiskanen T, Stenberg D, McCarley RW (1999) Adenosine and behavioral state control: adenosine increases c-Fos protein and AP1 binding in basal forebrain of rats. Brain Res Mol Brain Res 73:1-10.

Birnstiel S, Gerber U, Greene RW (1992) Adenosine-mediated synaptic inhibition: partial blockade by barium does not prevent antiepileptiform activity. Synapse 11:191-196.

Blanton MG, Lo Turco JJ, Kriegstein AR (1989) Whole cell recording from neurons in slices of reptilian and mammalian cerebral cortex. J Neurosci Methods 30:203-210.

Bridges AJ, Bruns RF, Ortwine DF, Priebe SR, Szotek DL, Trivedi BK (1988) N6-[2-(3,5-dimethoxyphenyl)-2-(2-

methylphenyl)ethyl]adenosine and its uronamide derivatives. Novel adenosine agonists with both high affinity and high selectivity for the adenosine $\mathrm{A}_{2}$ receptor. J Med Chem 31:1282-1285.

Brown SJ, James S, Reddington M, Richardson PJ (1990) Both $\mathrm{A}_{1}$ and $\mathrm{A}_{2 \mathrm{a}}$ purine receptors regulate striatal acetylcholine release. J Neurochem 55:31-38.

Brundege JM, Dunwiddie TV (1996) Modulation of excitatory synaptic transmission by adenosine released from single hippocampal pyramidal neurons. J Neurosci 16:5603-5612.

Brundege JM, Dunwiddie TV (1997) Role of adenosine as a modulator of synaptic activity in the central nervous system. Adv Pharmacol 39:353-391.

Bruns RF (1981) Adenosine antagonism by purines, pteridines and benzopteridines in human fibroblasts. Biochem Pharmacol 30:325-333.

Bruns RF, Lu GH, Pugsley TA (1986) Characterization of the $\mathrm{A}_{2}$ adenosine receptor labeled by $[3 \mathrm{H}] \mathrm{NECA}$ in rat striatal membranes. Mol Pharmacol 29:331-334.

Costenla AR, De Mendonca A, Sebastião A, Ribeiro JA (1999) An adenosine analogue inhibits NMDA receptor-mediated responses in bipolar cells of the rat retina. Exp Eye Res 68:367-370.

Davies LP, Cook AF (1995) Inhibition of adenosine kinase and adenosine uptake in guinea-pig CNS tissue by halogenated tubercidin analogues. Life Sci 56:PL345-349.

de Mendonca A, Sebastião AM, Ribeiro JA (1995) Inhibition of NMDA receptor-mediated currents in isolated rat hippocampal neurones by adenosine $A_{1}$ receptor activation. NeuroReport 6:1097-1100.

Dolphin AC, Forda SR, Scott RH (1986) Calcium-dependent currents in cultured rat dorsal root ganglion neurones are inhibited by an adenosine analogue. J Physiol (Lond) 373:47-61.

Dunwiddie TV, Diao L (2000) Regulation of extracellular adenosine in rat hippocampal slices is temperature dependent: role of adenosine transporters. Neuroscience 95:81-88.

Dunwiddie TV, Hoffer BJ (1980) Adenine nucleotides and synaptic transmission in the in vitro rat hippocampus. $\mathrm{Br} \mathrm{J}$ Pharmacol 69:59-68.

Dunwiddie TV, Miller KK (1993) Effects of adenosine and cadmium on presynaptic fiber spikes in the CA1 region of rat hippocampus in vitro. Neuropharmacology 32:1061-1068.

Dunwiddie TV, Hoffer BJ, Fredholm BB (1981) Alkylxanthines elevate hippocampal excitability. Evidence for a role of endogenous adenosine. Naunyn Schmiedebergs Arch Pharmacol 316:326-330.

Ford B, Holmes CJ, Mainville L, Jones BE (1995) GABAergic neurons in the rat pontomesencephalic tegmentum: codistribution with cholinergic and other tegmental neurons projecting to the posterior lateral hypothalamus. J Comp Neurol 363:177-196.

Fredholm BB, Battig K, Holmen J, Nehlig A, Zvartau EE (1999) Actions of caffeine in the brain with special reference to factors that contribute to its widespread use. Pharmacol Rev 51:83-133.

Geiger JD, Fyda D (1991) Adenosine transport in the CNS. In: Adenosine in the nervous system (Stone TW, ed), pp 1-23. San Diego: Academy.

Gerber U, Greene RW, Haas HL, Stevens DR (1989) Characterization of inhibition mediated by adenosine in the hippocampus of the rat in vitro. J Physiol (Lond) 417:567-578.

Golembiowska K, White TD, Sawynok J (1996). Adenosine kinase inhibitors augment release of adenosine from spinal cord slices. Eur J Pharmacol 307:157-162.

Greene RW, Haas HL (1991) The electrophysiology of adenosine in the mammalian central nervous system. Prog Neurobiol 36:329-341.

Greene RW, Haas HL, Hermann A (1985) Effects of caffeine on hippocampal pyramidal cells in vitro. Br J Pharmacol 85:163-169.

Haas HL, Greene RW (1988) Endogenous adenosine inhibits hippocampal CA1 neurones: further evidence from extra- and intracellular recording. Naunyn Schmiedebergs Arch Pharmacol $337: 561-565$

Hasuo H, Shoji S, Gallagher JP, Akasu T (1992) Adenosine inhibits the synaptic potenials in rat septal nucleus neurons mediated through pre- and postsynaptic $\mathrm{A}_{1}$-adenosine receptors. Neurosci Res 4:281-299.
Hawkins CF, Bagnara AS (1987) Adenosine kinase from human erythrocytes: kinetic studies and characterization of adenosine binding sites. Biochemistry 26:1982-1987.

Inglis WL, Semba K (1996) Colocalization of ionotropic glutamate receptor subunits with NADPH-diaphorase-containing neurons in the rat mesopontine tegmentum. J Comp Neurol 368:17-32.

Jones BE (1993) The organization of central cholinergic systems and their functional importance in sleep-waking states. Prog Brain Res 98:61-71.

Kamondi A, Williams JA, Hutcheon B, Reiner PB (1992) Membrane properties of mesopontine cholinergic neurons studied with the whole-cell patch-clamp technique: implications for behavioral state control. J Neurophysiol 64:1359-1372.

Kessey K, Mogul DJ (1998) Adenosine $\mathrm{A}_{2}$ receptors modulate hippocampal synaptic transmission via a cyclic-AMP-dependent pathway. Neuroscience 84:59-69.

Li H, Henry JL (1998) Adenosine $\mathrm{A}_{2}$ receptor mediation of pre- and postsynaptic excitatory effects of adenosine in rat hippocampus in vitro. Eur J Pharmacol 347:173-182.

Lloyd HG, Fredholm BB (1995) Involvement of adenosine deaminase and adenosine kinase in regulating extracellular adenosine concentration in rat hippocampal slices. Neurochem Int 26:387-395.

Luebke JI, McCarley RW, Greene RW (1993) Inhibitory action of muscarinic agonists on neurons in the rat laterodorsal tegmental nucleus in vitro. J Neurophysiol 70:2128-2135.

Maloney KJ, Mainville L, Jones BE (1999) Differential c-Fos expression in cholinergic, monoaminergic, and GABAergic cell groups of the pontomesencephalic tegmentum after paradoxical sleep deprivation and recovery. J Neurosci 19:3057-3072.

Mimouni M, Bontemps F, Van den Berghe G (1994) Kinetic studies of rat liver adenosine kinase. Explanation of exchange reaction between adenosine and AMP. J Biol Chem 269:17820-17825.

Mogul DJ, Adams ME, Fox AP (1994) Differential activation of adenosine receptors decreases $\mathrm{N}$-type but potentiates P-type $\mathrm{Ca}^{2+}$ current in hippocampal CA3 neurons. Neuron 10:327-334.

Oliet SH, Poulain DA (1999) Adenosine-induced presynaptic inhibition of IPSCs and EPSCs in rat hypothalamic supraoptic nucleus neurons. J Physiol (Lond) 520:815-825.

Pak MA, Haas HL, Decking UK, Schrader J (1994) Inhibition of adenosine kinase increases endogenous adenosine and depresses neuronal activity in hippocampal slices. Neuropharmacology 33:1049-1053.

Palmer TM, Stiles GL (1995) Adenosine receptors. Neuropharmacology 34:683-694.

Pelicano H, Maury G, Elalaoui A, Shafiee M, Imbach JL, Goody RS, Divita G (1997) Study of the substrate-binding properties of bovine liver adenosine kinase and inhibition by fluorescent nucleoside analogues. Eur J Biochem 248:930-937.

Porkka-Heiskanen T, Strecker RE, Thakkar M, Bjorkum AA, Greene RW, McCarley RW (1997) Adenosine: a mediator of the sleepinducing effects of prolonged wakefulness. Science 276:1265-1268.

Portas CM, Thakkar M, Rainnie DG, Greene RW, McCarley RW (1997) Role of adenosine in behavioral state modulation: a microdialysis study in the freely moving cat. Neuroscience 79:225-235.

Radulovacki M (1985) Role of adenosine in sleep in rats. Rev Clin Basic Pharmacol 5:327-339.

Rainnie DG, Grunze HCR, McCarley RW, Greene RW (1994) Adenosine inhibition of mesopontine cholinergic neurons: implications for EEG arousal. Science 263:689-692.

Redman S (1990) Quantal analysis of synaptic potentials in neurons of the central nervous system. Physiol Rev 70:165-198.

Ribeiro JA (1995) Purinergic inhibition of neurotransmitter release in the central nervous system. Pharmacol Toxicol 77:299-305.

Sanchez R, Leonard CS (1996) NMDA-receptor-mediated synaptic currents in guinea pig laterodorsal tegmental neurons in vitro. J Neurophysiol 76:1101-1111.

Scanziani M, Capogna M, Gahwiler BH, Thompson SM (1992) Presynaptic inhibition of miniature excitatory synaptic currents by baclofen and adenosine in the hippocampus. Neuron 9:919-927.

Scholz KP, Miller RJ (1991) Analysis of adenosine actions on $\mathrm{Ca}^{2+}$ currents and synaptic transmission in cultured rat hippocampal pyramidal neurones. J Physiol (Lond) 435:373-393.

Scholz KP, Miller RJ (1992) Inhibition of quantal transmitter release in the absence of calcium influx by a $G$ protein-linked adenosine receptor at hippocampal synapses. Neuron 8:1139-1150.

Semba K (1991) The cholinergic basal forebrain: a critical role in cortical arousal. Adv Exp Med Biol 295:197-218.

Semba K (1999) The mesopontine cholinergic system: a dual role in REM sleep and wakefulness. In: Handbook of behavioral state control, cellular and molecular mechanisms (Lydic R, Baghdoyan HA, eds), pp 161-180. New York: CRC.

Shen KZ, Johnson SW (1997) Presynaptic GABA B $_{\text {and }}$ adenosine $A_{1}$ receptors regulate synaptic transmission to rat substantia nigra reticulata neurones. J Physiol (Lond) 505:153-163.

Steriade M, Datta S, Pare D, Oakson G, Curro Dossi RC (1990) 
Neuronal activities in brainstem cholinergic nuclei related to tonic activation processes in thalamocortical systems. J Neurosci 10:2541-2559.

Steriade M, McCormick DA, Sejnowski TJ (1993) Thalamocortical oscillations in the sleeping and aroused brain. Science 262:679-685.

Strecker RE, Morairty S, Thakkar MM, Porkka-Heiskanen T, Basheer R, Dauphin LJ, Rainnie DG, Portas CM, Greene RW, McCarley RW (2000) Adenosinergic modulation of basal forebrain and preoptic/anterior hypothalamic neuronal activity in the control of behavioral state. Behav Brain Res 115:183-204.

Szymusiak R (1995) Magnocellular nuclei of the basal forebrain: substrates of sleep and arousal regulation. Sleep 18:478-500.

Szymusiak R, McGinty D (1989) Sleep-waking discharge of basal forebrain projection neurons in cats. Brain Res Bull 22:423-430.

Thakkar MM, Delgiacco RA, Strecker RE, McCarley RW (1999) Adenosine $\mathrm{A}_{1}$ inhibition of forebrain wake-active neurons: a combined unit recording and microdialysis study in freely behaving cats. Sleep 22:9.
Thorn JA, Jarvis SM (1996) Adenosine transporters. Gen Pharmacol 27:613-620.

Trussell LO, Jackson MB (1985) Adenosine-activated potassium conductance in cultured striatal neurons. Proc Natl Acad Sci USA $82: 4857-4861$

Tzounopoulos T, Janz R, Sudhof TC, Nicoll RA, Malenka RC (1998) A role for cAMP in long-term depression at hippocampal mossy fiber synapses. Neuron 21:837-845.

White TD (1996) Potentiation of excitatory amino acid-evoked adenosine release from rat cortex by inhibitors of adenosine kinase and adenosine deaminase and by acadesine. Eur J Pharmacol 303:27-38.

Wu LG, Saggau P (1994) Adenosine inhibits evoked synaptic transmission primarily by reducing presynaptic calcium influx in area CA1 of hippocampus. Neuron 12:1139-1148.

Yoon KW, Rothman SM (1991) Adenosine inhibits excitatory but not inhibitory synaptic transmission in the hippocampus. J Neurosci 11:1375-1380. 